\title{
Catenuloplanes japonicus gen. nov., sp. nov., nom. rev., a New Genus of the Order Actinomycetales
}

\author{
AKIRA YOKOTA, ${ }^{1 *}$ TOMOHIKO TAMURA, ${ }^{1}$ TORU HASEGAWA, ${ }^{1}$ AND LIANG H. HUANG ${ }^{2}$ \\ Institute for Fermentation, Osaka, 17-85, Juso-honmachi 2-chome, Yodogawa-ku, Osaka 532, Japan, ${ }^{1}$ \\ and Central Research Division, Pfizer, Inc., Groton, Connecticut $06340^{2}$
}

\begin{abstract}
Thirteen strains of motile arthrospore-bearing actinomycetes were isolated from soils in Japan, India, and Nepal. These organisms underwent differentiation into aerial and substrate mycelia in their growth cycles and produced motile spores arranged in chains on their aerial mycelia. Sporangia were not observed. The cell walls contained L-lysine, serine, glycine, D-glutamic acid, and D-alanine (cell wall type VI). Mycolic acids were absent; the major menaquinones were $\mathrm{MK}-9\left(\mathrm{H}_{8}\right)$ and $\mathrm{MK}-10\left(\mathrm{H}_{8}\right)$; the phospholipid type was type PIII. The taxonomic characteristics of these isolates are different from those of the previously described motile actinomycetes. The name Catenuloplanes japonicus gen. nov., sp. nov., nom. rev. is proposed for these organisms. The type strain is strain N381-16, which has been deposited in the Institute for Fermentation, Osaka as strain IFO 14176 and in the American Type Culture Collection as strain ATCC 31637.
\end{abstract}

Celmer et al. (1) described two actinomycete strains that produce the antibiotics CP-54715 and CP-54716 and gave them the name "Catenuloplanes japonicus." These two strains, designated N381-16 $\mathrm{T}(\mathrm{T}=$ type strain) and N406-14, were deposited in the American Type Culture Collection as strains ATCC $31637^{\mathrm{T}}$ and ATCC 31638 , respectively. Since these strains produced straight chains of spores on their aerial mycelia and the spores became motile when they were suspended in water, they were placed in a new genus, "Catenuloplanes."

In the course of isolating microorganisms that are rarely occurring members of genera belonging to the order Actinomycetales, we isolated 11 additional, unusual filamentous bacteria from soils in Japan, India, and Nepal. These organisms had morphological, physiological, and chemotaxonomic characteristics that placed them in the order Actinomycetales but precluded their placement in any of the previously described genera of that order. They had type VI cell walls, lacked mycolic acids, formed motile arthrospores, and contained L-lysine instead of diaminopimelic acid (DAP) in their cell walls and MK-9( $\left.\mathrm{H}_{8}\right)$ and MK-10 $\left(\mathrm{H}_{8}\right)$ as their respiratory quinones. The genera Sporichthya (17), Actinosynnema (9), and Actinokineospora (7) are previously described genera of motile arthrospore-bearing actinomycetes (8), but our isolates are taxonomically distinct from members of these genera and thus from all members of the order Actinomycetales.

In this paper we describe the characterization and classification of the motile actinomycete isolates, and we propose that they should be included in a new genus, Catenuloplanes, as Catenuloplanes japonicus gen. nov., sp. nov., nom. rev.

\section{MATERIALS AND METHODS}

Microorganisms and cultural conditions. The following strains were used in this study: strains N381-16 ${ }^{\mathrm{T}}$ (= IFO $14176^{\mathrm{T}}=$ ATCC $31637^{\mathrm{T}}$ ) (IFO, Institute for Fermentation, Osaka, Japan; ATCC, American Type Culture Collection, Rockville, Md.), N406-14 (= IFO 14177 = ATCC 31638), RA 327 through RA 332, RA 336 through RA 338, RA 343, and

\footnotetext{
${ }^{*}$ Corresponding author.
}

RA 344. Strains N381-16 ${ }^{\text {T }}$ and RA 336 through RA 338 were isolated from soils in Japan; strains N406-14 and RA 327 through RA 332 were isolated from soils in India; and strains RA 343 and RA 344 were isolated from soils in Nepal. Strains RA 327 through 332, RA 336 through RA 338, RA 343 , and RA 344 were isolated on a medium containing $1.0 \%$ soluble starch, $0.1 \%$ casein, $0.05 \% \mathrm{~K}_{2} \mathrm{HPO}_{4}$, and $1.5 \%$ agar ( $\mathrm{pH} 7.0$ to 7.5 ) supplemented with $25 \mu \mathrm{g}$ of nalidixic acid per $\mathrm{ml}, 12.5 \mu \mathrm{g}$ of kanamycin per $\mathrm{ml}, 5.0 \mu \mathrm{g}$ of cefsulodin per $\mathrm{ml}$, and $6.25 \mu \mathrm{g}$ of kabicidin per ml.

Cultural observations. Cultural characteristics were recorded after 14 days of incubation at $28^{\circ} \mathrm{C}$. Standardized media and methods of the International Streptomyces Project (ISP) (27) were used for cultivation. The colors are described below in common terms, but exact colors were determined by comparison with color chips from the Color Harmony Manual, 4th ed. (1a). The temperature range for growth was determined on ISP medium 2 agar slants at temperatures between 5 and $50^{\circ} \mathrm{C}$.

Morphological observations. Motility was observed under a light microscope by using cells in the logarithmic phase grown on HV agar (10) or cells in the stationary phase after incubation at $28^{\circ} \mathrm{C}$ for $1 \mathrm{~h}$ in $0.01 \mathrm{M}$ phosphate buffer $(\mathrm{pH}$ 7.0 ) containing $10 \%$ soil extract. Flagellation was observed with a model JEM-1200EX transmission electron microscope (JEOL, Ltd., Tokyo, Japan) after shadowing with platinum-palladium. Cultures grown on HV agar for 14 days at $28^{\circ} \mathrm{C}$ were observed with a model JSM-5400 scanning electron microscope (JEOL, Ltd.). Samples for scanning electron microscopy were prepared by cutting an agar block on which a culture grew, fixing the block in osmium tetroxide vapor at room temperature for $4 \mathrm{~h}$, and sputter-coating the preparation with palladium under a vacuum.

Physiological characterization. The following methods were used for physiological characterization. An inoculum was prepared by transferring an appropriate culture from a lyophile into ATCC medium 172 broth and growing it for 6 days at $28^{\circ} \mathrm{C}$ on a shaker. The preparation was then centrifuged for $20 \mathrm{~min}$, washed with sterile water, and plated on media commonly used for identification of members of the Actinomycetales (27). Carbohydrate utilization was determined by the method of Pridham and Gottlieb (23), and other biochemical tests were performed by the methods of Gordon et al. (4) and Huang (12). 
Chemotaxonomic characteristics. (i) Peptidoglycan analysis. Cell walls were prepared from ca. $500 \mathrm{mg}$ of dry cells by mechanical disruption with an ultrasonic oscillator and were purified as described by Schleifer and Kandler (26). The amino acid compositions of complete wall hydrolysates were determined as phenylthiocarbamoyl derivatives according to the manufacturer's instructions (32) by high-performance liquid chromatography (HPLC), using a model LC-6AD instrument (Shimadzu Co., Ltd., Kyoto, Japan) equipped with a Wakopak WS-PTC column (Wako Pure Chemical Industries, Ltd., Osaka, Japan). The amino acid compositions and isomers of DAP were also determined by developing preparations on cellulose thin-layer chromatography plates (Tokyo Kasei Co., Ltd., Tokyo, Japan), using twodimensional descending chromatography as described by Harper and Davis (6). The configurations of amino acids were determined by measuring the amino acid contents of a hydrolysate before and after incubation with D- and L-amino acid oxidase (alanine and serine), L-lysine decarboxylase (lysine), L-ornithine decarboxylase (ornithine), or L-glutamic acid decarboxylase (glutamic acid), using the method of Kandler and König (15).

(ii) Cell wall sugar analysis. Cell walls were hydrolyzed with $2 \mathrm{~N} \mathrm{HCl}$ at $100^{\circ} \mathrm{C}$ for $2 \mathrm{~h}$, dried in vacuo, and then analyzed by the method described by Mikami and Ishida (20), using a Shimadzu model LC-5A HPLC instrument equipped with a Shim-pack ISA $07 / \mathrm{S} 2504$ column ( 250 by 4 $\mathrm{mm}$ ) and a Shimadzu model RE-530 spectrofluorometer.

(iii) Glycolyl analysis. The glycolyl test was carried out by the method of Uchida and Aida (31).

(iv) Analysis of cellular fatty acids. Fatty acids were extracted from dry cells $(50 \mathrm{mg})$ by acid methanolysis and were examined with a gas-liquid chromatograph (model GC-9A; Shimadzu) equipped with a glass column $(2 \mathrm{~mm}$ by $5 \mathrm{~m}$ ) containing $10 \%$ diethyleneglycol succinate on Chromosorb $\mathrm{W}$ at $180^{\circ} \mathrm{C}(30)$. The quantitative fatty acid data were numerically analyzed by using the NTSYS-pc program package (Applied Biostatistics, Inc., Setanket, N.Y.), and the results are presented below as a dendrogram drawn by using unweighted pair group arithmetic average clustering (28).

(v) Analysis of polar lipids. Free lipids were extracted from dry cells $(100 \mathrm{mg})$, purified by the method of Minnikin et al. (22), and examined by two-dimensional thin-layer chromatography, using Kieselgel $60 \mathrm{~F}_{254}$ plates. Lipids were revealed by spraying the plates with $10 \%$ molybdophosphoric acid in ethanol and then heating them at $140^{\circ} \mathrm{C}$ for $10 \mathrm{~min}$. The following specific spray reagents were used: $\alpha$-naphthol for sugars and ninhydrin for amino groups.

(vi) Analysis of mycolic acids. The mycolic acid analysis was performed by the method of Minnikin et al. (21).

(vii) Analysis of isoprenoid quinones. Menaquinones were extracted from $200 \mathrm{mg}$ of dry cells with chloroform-methanol $(2: 1, \mathrm{vol} / \mathrm{vol})$, purified on thin-layer chromatography plates by using benzene as a solvent, extracted with diethylether, dried in a stream of nitrogen, and then analyzed by HPLC by using a Shimadzu model LC-5A instrument equipped with a Zorbax octyldecyl silane column ( 4.6 by $150 \mathrm{~mm}$ ), a Shimadzu model SPD-6A spectrometer, and a Shimadzu Chromatopak; methanol-isopropylether $(7: 1$, vol/vol) was the eluent used.

DNA base composition. DNA was obtained by the method of Saito and Miura (25). The G+C content of the DNA was determined by the method of Mesbah et al. (19) after treatment with P1 nuclease and alkaline phosphatase; HPLC was performed with a Shimadzu model LC-6AD instrument equipped with a column containing Cosmosil $5 \mathrm{C}_{18}$ - $\mathrm{AR}(4.6$ by $150 \mathrm{~mm}$; Nacalai Tesque, Inc., Tokyo, Japan).

DNA-DNA hybridization. Levels of DNA relatedness between strains were determined fluorometrically by the method of Ezaki et al. (2), using biotinylated DNA.

\section{RESULTS AND DISCUSSION}

Morphological observations. All strains were gram-positive, non-acid-fast, aerobic organisms with branched hyphae and therefore were members of the order Actinomycetales Buchanan. A nonfragmenting, yellowish orange to orange substrate mycelium was formed. Monopodially or dichotomously branched aerial mycelia developed sparsely in strains N381-16 ${ }^{\mathrm{T}}$, N406-14, RA 328, RA 332, and RA 344, but were not observed in the other strains. Spores were formed in chains. The spore chains and aerial mycelium often aggregated into clusters resembling flowers or sporodochia, which were compact and flat at the center of a colony but filamentous toward the edge of the colony. Morphological observations of a 14-day-old culture grown on oatmeal agar revealed the presence of an aerial mycelium with short spore chains arranged in spirals of one to two turns (hooked or rarely flexuous), which arose from the substrate mycelium or the aerial mycelium. Several spores per spore chain were observed. The spores were rod shaped and straight or curved ( 0.6 to 0.8 by 2 to $4 \mu \mathrm{m})$ and were formed by fragmentation of the hyphae (arthrospores); the spores had smooth surfaces, as revealed by scanning electron microscopy (Fig. 1). The spores were motile when they were suspended in nutrient broth, water, or phosphate buffer containing soil extract and were peritrichous, as revealed by transmission electron microscopy (Fig. 2).

Growth characteristics. Strain N381-16 ${ }^{\mathrm{T}}$ and all of the other isolates had almost the same cultural characteristics. They exhibited good growth on yeast extract-malt extract agar, inorganic salts-starch agar, gelatin agar (5), starch agar, Czapek-sucrose agar, glucose-aspargine agar, and casein agar. In general, the vegetative mycelia of the strains were pale orange to orange yellow, and the aerial mycelia were white to pale yellow. The strains produced a pale yellow soluble pigment on Czapek-sucrose agar, glucose-aspargine agar, and calcium malate agar. The colonial characteristics of strain N381-16 ${ }^{\mathbf{T}}$ on various media are shown in Table 1. Five strains (N406-14, RA 330, RA 331, RA 332, and RA 344) differed from the other strains by producing darker colonies (with colors ranging from orange to brown to black) and by producing a dark soluble pigment on some media.

Physiological and biochemical characteristics. Biochemical and physiological properties of strain $\mathrm{N} 381-16^{\mathrm{T}}$ are shown in Table 2. This strain utilized many organic acids and carbohydrates as carbon sources. Acids were produced from many carbohydrates. All of the other isolates had nearly the same biochemical and physiological features.

Chemotaxonomic characteristics. As shown in Table 3, a chemical analysis of the cells gave very similar results for all of the isolates. The cell walls contained glutamate, serine, glycine, alanine, and lysine (molar ratio, ca. 1:1:1:1:1) in addition to a small amount of ornithine, which indicates that the cell wall type is type VI according to the classification of Lechevalier and Lechevalier (16). The determination of the configurations of the amino acids revealed the presence of D-alanine, D-glutamic acid, L-lysine, and equal amounts of $D$ - and L-serine, which suggested that the peptidoglycan type is type $\mathrm{A}$, most probably $\mathrm{A} 3 \alpha$, as defined by Schleifer and Kandler (26). The cell wall sugars mannose, xylose, and 


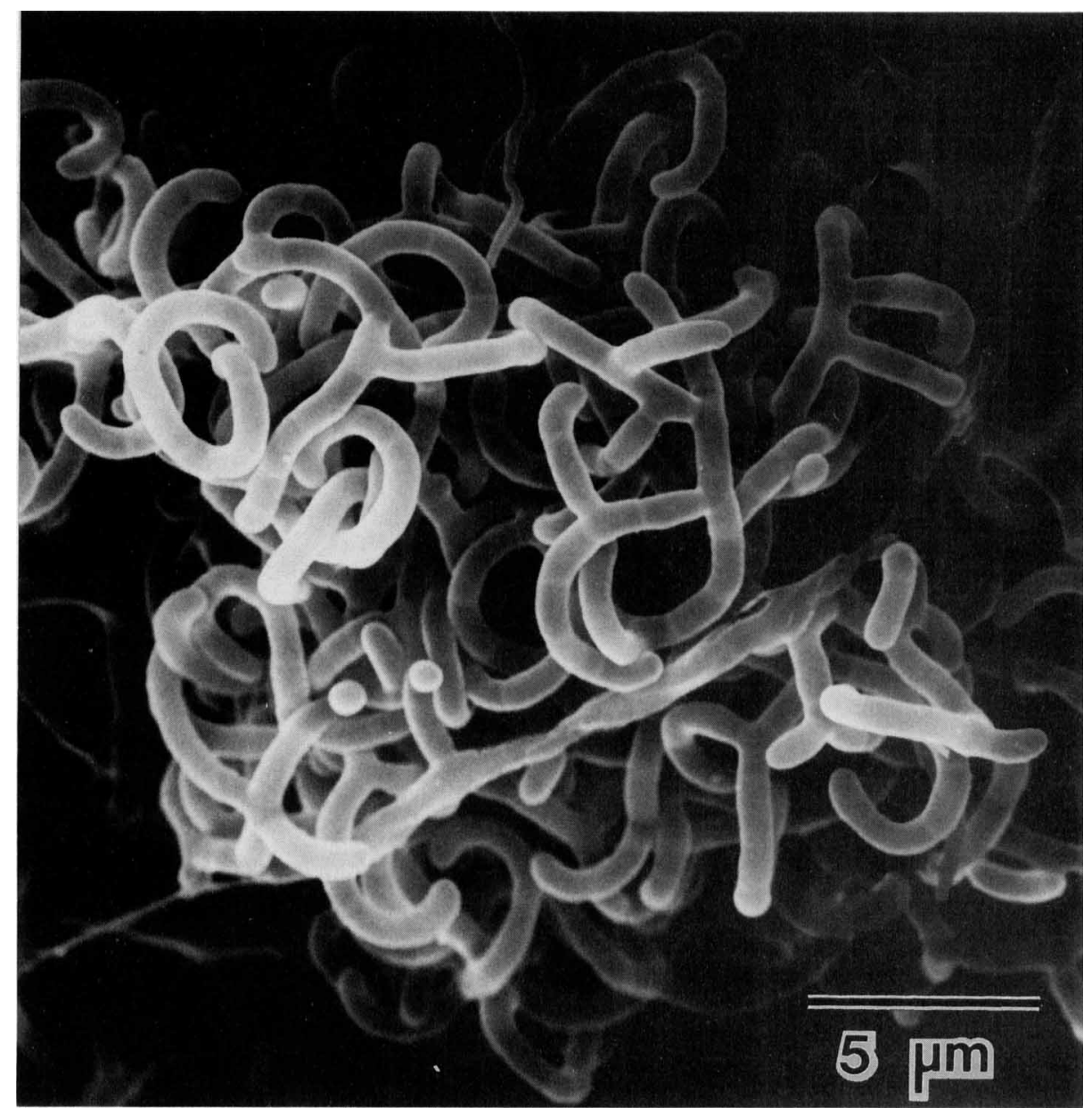

FIG. 1. Scanning electron micrograph of arthrospore chains of strain $\mathrm{N} 381-16^{\mathrm{T}}$.

glucose were found in all strains; in addition, three strains (RA 330, RA 331, and RA 332) contained galactose.

The strains contained octadecenoic acid (18:1) and hexadecanoic acid (16:0) or anteiso-heptadecanoic acid (a17:0) as major cellular fatty acids. The cellular fatty acid compositions of the isolates and of strains N381-16 ${ }^{\mathrm{T}}$ and N406-14 are shown in Table 4 . The results of a cluster analysis based on fatty acid compositions are shown in Fig. 3. Mycolic acids were absent. The $\mathrm{G}+\mathrm{C}$ contents of the DNAs were between 71.0 and $72.7 \mathrm{~mol} \%$. The major menaquinones were MK$9\left(\mathrm{H}_{8}\right)$ and $\mathrm{MK}-10\left(\mathrm{H}_{8}\right)$; in addition, small amounts of MK$9\left(\mathrm{H}_{6}\right)$ and $\mathrm{MK}-10\left(\mathrm{H}_{6}\right)$ were also present. The diagnostic phospholipids detected were diphosphatidylglycerol, phosphatidylglycerol, phosphatidylinositol, phosphatidylcholine, and phosphatidylethanolamine (type PIII as defined by Lechevalier et al. [18]).

DNA-DNA hybridization. As Table 5 shows, the DNADNA hybridization data indicated that the 13 strains could be divided into the following six DNA relatedness groups: one group containing strains RA 327, RA 328, and RA 329; one group containing strains RA 330, RA 331, and RA 332; one group containing strains RA 336, RA 337, RA 338, and RA 344; one group containing strain RA 343; one group containing strain $\mathrm{N} 381-16^{\mathrm{T}}$; and one group containing strain N406-14.

The isolates described in this paper resemble members of the actinoplanete genera (3), such as the genera Actinoplanes (except Actinoplanes caeruleus) (11), Dactylosporangium, and Pilimelia, in having motile spores, but differ in containing L-lysine instead of meso-DAP in their cell walls and in producing spores on mycelia arranged in chains instead of enclosed in a sporangial wall (Table 6).

In addition to the actinoplanetes, the following other motile spore-forming genera exist: Planomonospora, Planobispora, Spirillospora, and Streptoalloteichus. However, the members of these genera have morphological and chemotaxonomic features that differ from those of our isolates (Table 6). The members of other motile actinomycete genera, including the genera Dermatophilus and Geodermatophilus, form no aerial mycelia and have different modes of spore formation and cell wall types.

Abundant aerial mycelia are produced by Streptoalloteichus and Actinosynnema species, which have cell wall types and menaquinone systems that are different from those of our isolates. Members of the genus Streptoalloteichus produce subspherical to peanut shell-shaped sporangia as well as chains of spores. As the name implies, Actinosynnema species form synnemata on which chains of spores are produced. The genus Sporichthya is characterized by cell wall type I and the absence of substrate mycelium. Kineosporia species are characterized by the presence of both LL- and meso-DAP in their cell walls and the absence of 


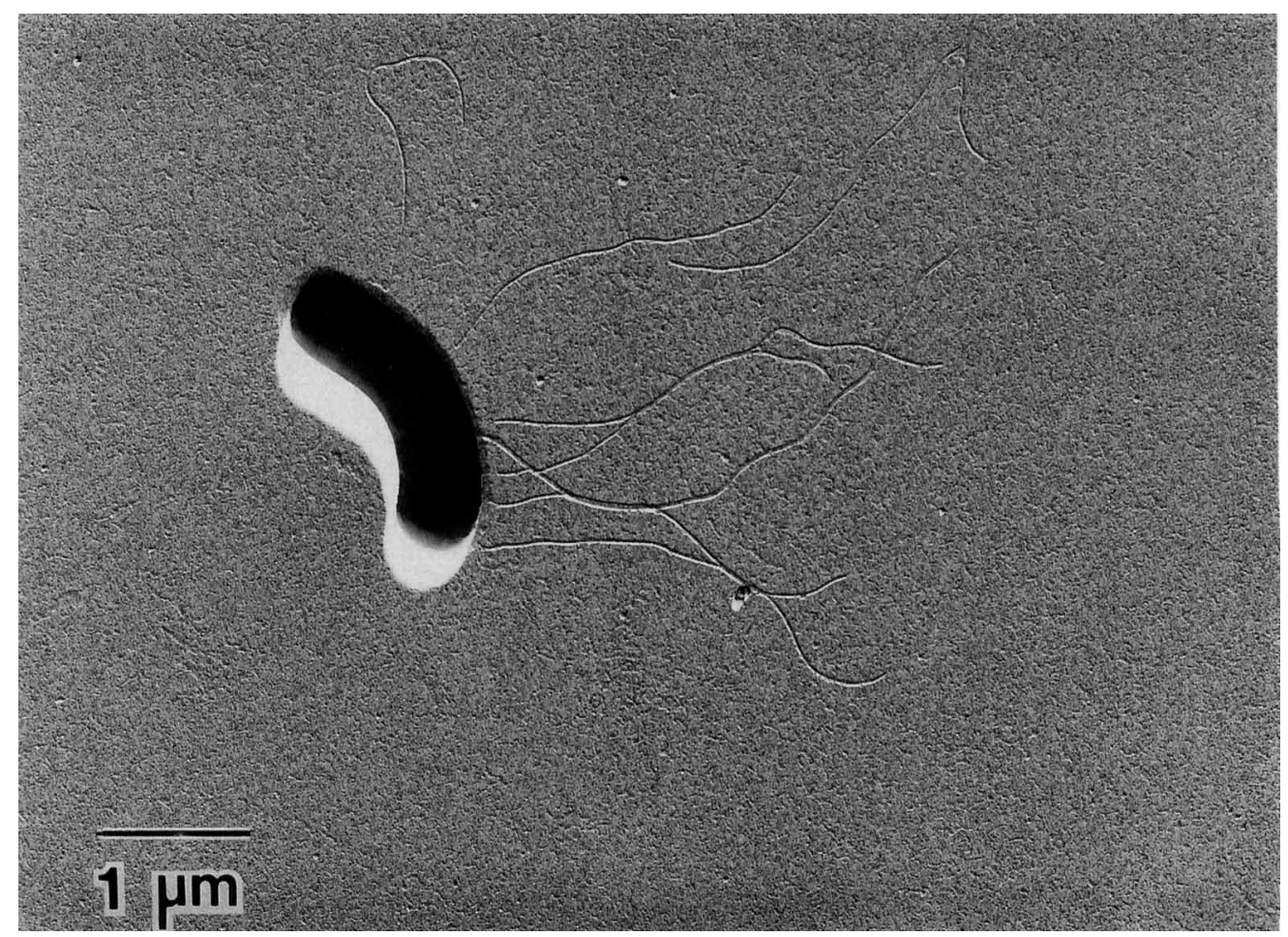

FIG. 2. Transmission electron micrograph of a motile spore of strain $\mathrm{N} 381-17^{\mathrm{T}}$ with peritrichous flagella.

aerial mycelia (13). Among the motile actinomycetes described above, the members of the genera Sporichthya, Actinokineospora, and Actinosynnema are known to be motile arthrospore-bearing actinomycetes (8). However, the members of all three of these genera have morphological, physiological, and chemotaxonomic characteristics that are distinct from the characteristics of our isolates.

Among the genera in the order Actinomycetales that have type VI cell walls as defined by Lechevalier and Lechevalier (16) are the genera Promicromonospora, Oerskovia, and
Jonesia (24), which are members of the family Cellulomonadaceae (29). Members of these genera have peptidoglycan type $A 4 \alpha$ of Schleifer and Kandler (26). The genus Cellulomonas is also included in this family. Members of these four genera resemble our isolates in not having meso-DAP in their cell walls but differ in their menaquinone system [MK-9( $\left.\left.\mathrm{H}_{4}\right)\right]$, phospholipid type (type PV), absence of aerial mycelium, and mode of spore formation. The members of the genus Cellulomonas also differ in having type VIII cell walls. Members of the genus Microbacterium, a genus of

TABLE 1. Growth characteristics of strain N381-16 ${ }^{\mathrm{T}}$ on various media

\begin{tabular}{|c|c|c|c|c|}
\hline Medium & Growth & $\begin{array}{c}\text { Aerial } \\
\text { mycelium }\end{array}$ & $\begin{array}{l}\text { Diffusible } \\
\text { pigments }\end{array}$ & Color of colonies ${ }^{a}$ \\
\hline Yeast extract-malt extract agar (ISP medium 2) & Good & Absent & Pale yellow & 4ea to 4ga (yellowish orange) \\
\hline Oatmeal agar (ISP medium 3) & Moderate & Sparse & Absent & $3 \mathrm{ca}, 4 \mathrm{ea}$ to $4 \mathrm{ga}$ (yellowish orange) \\
\hline Inorganic salts-starch agar (ISP medium 4) & Good & Absent & Pale yellow & $4 \mathrm{ea}$ to $4 \mathrm{na}$ (pale orange to orange) \\
\hline Glycerol-asparagine agar & Moderate & Sparse & Absent & 3ea to $4 \mathrm{ga}$ (pale yellowish orange) \\
\hline Gelatin agar $b$ & Good & Sparse & Absent & 3 ia to 3 na (orange yellow) \\
\hline Starch agar (Waksman medium 21) & Good & Absent & Absent & 3ia (orange yellow) \\
\hline Potato-carrot agar & Moderate & Sparse & Absent & Colorless to dull white \\
\hline Tap water agar & Scant & Sparse & Absent & Colorless \\
\hline Czapek-sucrose agar & Good & Absent & Pale yellow & 3ea (pale yellowish orange) \\
\hline Glucose-asparagine agar & Good & Absent & Pale yellow & $3 g a$ to 4 ga (yellowish orange) \\
\hline Glucose-yeast extract agar & Good & Absent & Absent & 4ea to 4ga (orange) \\
\hline Emerson's agar & Good & Absent & Absent & Dull white \\
\hline Nutrient agar & Moderate & Absent & Absent & 3ea to 3ga (pale orange yellow) \\
\hline Bennett's agar & Good & Absent & Absent & 4ia to 4la (orange) \\
\hline Gordon and Smith's tyrosine agar & Moderate & Absent & Pale yellow & 3ia (yellowish orange) \\
\hline Casein agar & Good & Absent & Absent & $4 \mathrm{na}$ to $4 \mathrm{pa}$ (bright orange) \\
\hline Calcium malate agar & Moderate & Absent & Pale yellow & 3ea to 3ga (pale yellowish orange) \\
\hline
\end{tabular}

\footnotetext{
${ }^{a}$ See reference $1 \mathrm{a}$.
}

${ }^{b}$ See reference 5 . 
TABLE 2. Biochemical and physiological properties of strain $\mathrm{N} 381-16^{\mathrm{T}}$

\begin{tabular}{|c|c|}
\hline Characteristic & Strain N381-16 ${ }^{\mathrm{T}}$ \\
\hline Gram stain ....... & + \\
\hline Acid fastness ......................... & - \\
\hline Melanin production & - \\
\hline 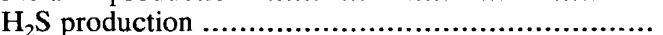 & + \\
\hline Nitrate reduction & - \\
\hline 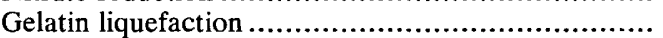 & + \\
\hline \multicolumn{2}{|l|}{ Hydrolysis of: } \\
\hline 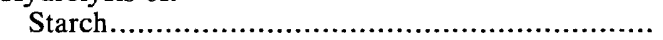 & + \\
\hline Hippurate & - \\
\hline Cellulose & - \\
\hline \multicolumn{2}{|l|}{ Decomposition of: } \\
\hline Adenine ............ & - \\
\hline 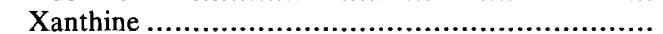 & - \\
\hline Hypoxanthine & - \\
\hline Calcium malate ................................................... & + \\
\hline 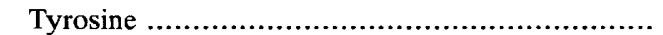 & + \\
\hline 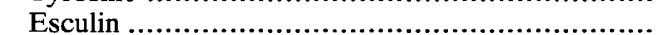 & + \\
\hline 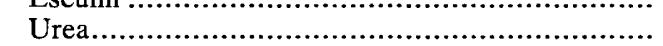 & + \\
\hline 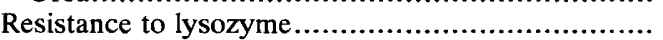 & - \\
\hline Coagulation and peptonization of milk ................... & + \\
\hline \multicolumn{2}{|l|}{ Utilization of: } \\
\hline Acetate ....... & + \\
\hline 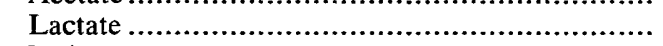 & + \\
\hline Malate & + \\
\hline 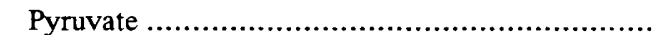 & + \\
\hline Succinate .................................................... & + \\
\hline 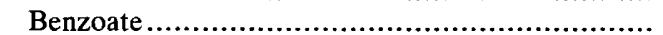 & - \\
\hline Citrate & - \\
\hline 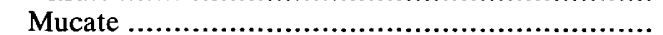 & _ \\
\hline Oxalate ............................... & - \\
\hline L-Arabinose & + \\
\hline Cellobiose & + \\
\hline Fructose & + \\
\hline 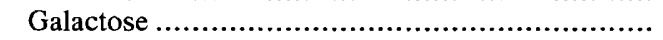 & + \\
\hline Glucose & + \\
\hline 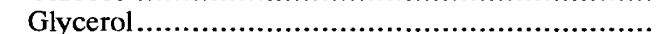 & + \\
\hline 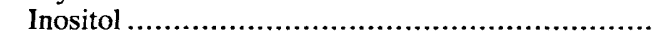 & + \\
\hline Lactose & + \\
\hline 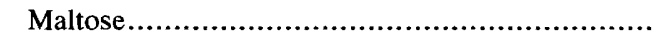 & + \\
\hline Mannitol & + \\
\hline Melezitose & + \\
\hline Melibiose & + \\
\hline 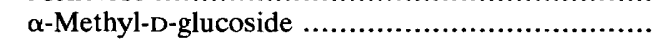 & + \\
\hline 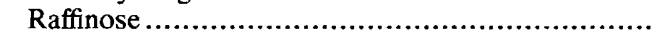 & + \\
\hline 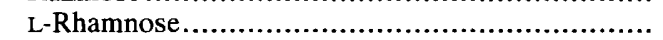 & + \\
\hline 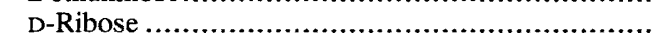 & + \\
\hline Salicin & + \\
\hline Starch........................................................ & + \\
\hline Sucrose & + \\
\hline Trehalose & + \\
\hline D-Xylose & + \\
\hline 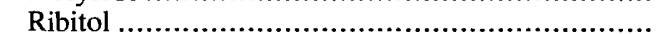 & - \\
\hline Galactitol ........... & - \\
\hline 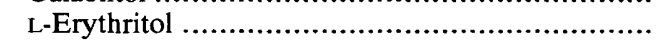 & - \\
\hline 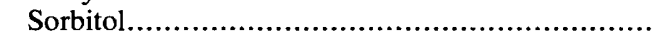 & - \\
\hline L-Sorbose & - \\
\hline \multicolumn{2}{|l|}{ Acid produced from: } \\
\hline L-Arabinose ................. & + \\
\hline 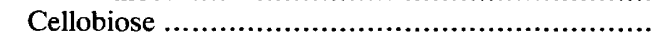 & + \\
\hline Fructose & + \\
\hline Galactose & + \\
\hline Glucose & + \\
\hline 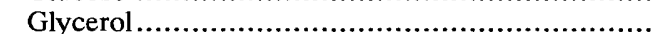 & + \\
\hline 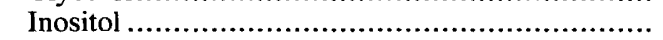 & + \\
\hline Lactose & + \\
\hline Maltose ........................................................... & + \\
\hline 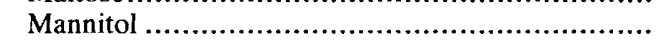 & + \\
\hline
\end{tabular}

Continued
TABLE 2. Biochemical and physiological properties of strain N381-16 ${ }^{\mathrm{T}}$

\begin{tabular}{|c|c|}
\hline Characteristic & $\begin{array}{c}\text { Strain } \\
\text { N381-16 }\end{array}$ \\
\hline Mannose. & + \\
\hline Melibiose. & + \\
\hline Melezitose...... & + \\
\hline$\alpha$-Methyl-D-glucoside ..... & + \\
\hline Raffinose .......................... & + \\
\hline L-Rhamnose........................... & + \\
\hline D-Ribose .............................. & + \\
\hline Salicin ................. & + \\
\hline Starch........ & + \\
\hline Sucrose.......................... & + \\
\hline Trehalose & + \\
\hline D-Xylose & + \\
\hline 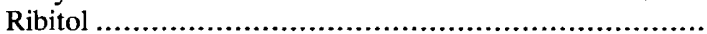 & - \\
\hline 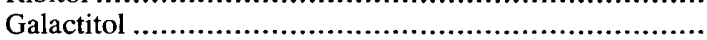 & - \\
\hline 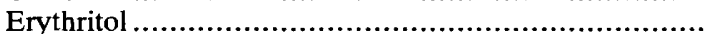 & - \\
\hline Sorbitol.... & - \\
\hline 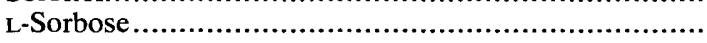 & - \\
\hline
\end{tabular}

actinobacteria (14), also have type VI cell walls, but they have type B (B1 $\alpha$ and B1 $\beta$ ) peptidoglycan as defined by Schleifer and Kandler (26).

Thus, on the basis of morphological, biochemical, and chemical criteria, our new isolates can be distinguished readily from the previously described motile actinomycetes and warrant a new taxon. Therefore, we propose that the strains should be classified in a new genus, Catenuloplanes, with type species Catenuloplanes japonicus sp. nov. The DNA-DNA hybridization data suggest that the genus Catenuloplanes is genetically heterogeneous. The dendrogram based on the quantitative fatty acid data (Fig. 3) also shows that the isolates can be divided into six groups, which correlate well with the DNA-DNA relatedness groups. However, no other phenotypic characteristics that differentiate the six DNA relatedness groups from one another have been found. After finding distinguishing characteristics for each group, we will reconsider the intrageneric relationships.

Much further work, including a comparative analysis of $16 \mathrm{~S}$ rRNA sequences and DNA-rRNA hybridization between members of the genus Catenuloplanes and representatives of other actinomycete families and related genera of actinobacteria, will be necessary to determine the relationship of the proposed new genus to the previously described actinomycete families. Meanwhile, the genus Catenuloplanes should be considered one of the several genera of the order Actinomycetales whose familial placement is uncertain.

Description of Catenuloplanes gen. nov. Catenuloplanes (Ca.te.nul.o.plan' es. L. f. n. catenula, short chain; Gr. n. planes, a wanderer; Gr. n. Catenuloplanes, a wanderer, a motile cell of a short chain) cells are gram positive and not acid fast and form truly branching hyphae. Nonfragmenting, yellowish orange to orange substrate mycelium is formed. Monopodially or dichotomously branched aerial mycelium develops sparsely. Spores are formed in chains. The aerial mycelium contains short spore chains arranged in spirals having one or two turns that are hooked or rarely flexuous. The spore chains and aerial mycelium often aggregate into clusters resembling a flower or a sporodochium. The spores are rod shaped, straight or curved ( 0.6 to 0.8 by 2 to $4 \mu \mathrm{m})$ with smooth surfaces, and motile by means of peritrichous flagella. 
TABLE 3. Chemotaxonomic characteristics of the isolates ${ }^{a}$

\begin{tabular}{|c|c|c|c|c|c|c|c|c|c|c|c|c|c|}
\hline \multirow{2}{*}{ Strain } & \multirow{2}{*}{$\begin{array}{c}\mathrm{G}+\mathrm{C} \\
\text { content } \\
\text { of DNA } \\
(\mathrm{mol} \%)\end{array}$} & \multirow{2}{*}{$\begin{array}{l}\text { Phospho- } \\
\text { lipid type }\end{array}$} & \multicolumn{4}{|c|}{ Menaquinone composition ${ }^{b}$} & \multicolumn{6}{|c|}{ Amino acid composition of cell walls (molar ratio) } & \multirow{2}{*}{$\begin{array}{c}\text { Galactose } \\
\text { in cell } \\
\text { walls }^{c}\end{array}$} \\
\hline & & & MK-9(- $\left.\mathbf{H}_{6}\right)$ & MK- $9\left(\mathbf{H}_{8}\right)$ & $\mathrm{MK}-10\left(\mathrm{H}_{6}\right)$ & MK-10( $\left.\mathrm{H}_{8}\right)$ & Glycine & D-Glutamate & L-Lysine & D-Alanine & $\begin{array}{l}\text { D- and } \\
\text { L-Serine }\end{array}$ & $\begin{array}{c}\text { Glucos- } \\
\text { amine }\end{array}$ & \\
\hline FA 327 & 71.3 & PIII & + & +++ & + & $+t$ & 1.15 & 1.00 & 0.90 & 0.89 & 0.92 & 0.90 & - \\
\hline FA 328 & 71.6 & $\mathrm{ND}^{d}$ & & +++ & + & ++ & 1.20 & 1.00 & 0.77 & 0.87 & 1.01 & 1.07 & - \\
\hline FA 329 & 71.9 & ND & + & +++ & + & $+t$ & 1.19 & 1.00 & 0.77 & 0.89 & 1.03 & 1.02 & - \\
\hline EA 330 & 72.4 & PIII & + & +++ & + & ++ & 1.12 & 1.00 & 0.71 & 0.85 & 0.88 & 0.86 & + \\
\hline RA 331 & 72.2 & PIII & + & $+t+$ & + & ++ & 1.15 & 1.00 & 0.79 & 0.88 & 0.93 & 0.97 & + \\
\hline RA 332 & 72.7 & ND & + & +++ & + & ++ & 1.21 & 1.00 & 0.88 & 0.96 & 0.94 & 0.99 & + \\
\hline RA 336 & 72.4 & PIII & & +++ & + & ++ & 1.35 & 1.00 & 1.03 & 0.98 & 1.06 & 0.32 & - \\
\hline RA 337 & 72.0 & ND & + & +++ & + & ++ & 1.20 & 1.00 & 1.04 & 0.98 & 0.98 & 0.60 & - \\
\hline RA 338 & 72.3 & ND & & +++ & + & ++ & 1.33 & 1.00 & 1.10 & 0.96 & 1.03 & 0.36 & - \\
\hline RA 343 & 71.1 & ND & & ++ & + & ++ & 1.16 & 1.00 & 1.03 & 0.95 & 0.98 & 0.75 & - \\
\hline RA 344 & 72.4 & ND & + & +++ & + & +++ & 1.28 & 1.00 & 0.83 & 0.85 & 0.98 & 0.76 & - \\
\hline $\mathrm{N} 381-16^{\mathrm{T}}$ & 71.0 & PIII & + & +++ & + & ++ & 1.10 & 1.00 & 0.77 & 0.71 & 0.91 & 0.81 & - \\
\hline N406-14 & 72.2 & PIII & + & +++ & + & ++ & 1.27 & 1.00 & 1.00 & 1.02 & 1.06 & 0.92 & - \\
\hline
\end{tabular}

a No strain contained mycolic acids: the glycolate test was positive.

$b+,<10 \%$;,++ 10 to $30 \%$;,$+++>30 \%$.

$c+$, present; - , absent. All strains contained xylose, mannose, and glucose in their cell walls.

${ }^{d} \mathrm{ND}$, not determined.

Strictly aerobic. Hydrogen sulfide is produced. Nitrate is not reduced to nitrite. Gelatin liquefaction is positive. Starch is hydrolyzed, but hippurate is not hydrolyzed. Adenine, xanthine, hypoxanthine, and cellulose are not decomposed or hydrolyzed. Decomposes calcium malate, tyrosine, esculin, and urea. Not resistant to lysozyme. Milk is coagulated and peptonized. Acids are produced from many carbohydrates. Many organic acids and carbohydrates are utilized as carbon sources.

Cell walls contain D-glutamate, D-serine, L-serine, glycine, D-alanine, and L-lysine (cell wall type VI), and mannose, xylose, and glucose are present as cell wall sugars. Mycolic acids are absent. The $\mathrm{G}+\mathrm{C}$ contents of the DNAs are between 71.0 and $72.7 \mathrm{~mol} \%$. The major menaquinones are MK-9 $\left(\mathrm{H}_{8}\right)$ and MK-10 $\left(\mathrm{H}_{8}\right)$; in addition, small amounts of MK-9 $\left(\mathrm{H}_{6}\right)$ and MK-10 $\left(\mathrm{H}_{6}\right)$ are also present. Diphosphatidylglycerol, phosphatidylglycerol, phosphatidylinositol, phosphatidylcholine, and phosphatidylethanolamine are present as diagnostic phospholipids (type PIII).

The type species is Catenuloplanes japonicus.
Description of Catenuloplanes japonicus sp. nov., nom. rev. Catenuloplanes japonicus (ja.pon' i.cus. M. L. neut. adj. japonicus, pertaining to Japan). The description of the species is the same as the description of the genus. Spores are motile when they are suspended in a nutrient broth and are peritrichous. Strictly aerobic. Good growth occurs at temperatures between 21 and $28^{\circ} \mathrm{C}$. The organism grows well on yeast extract-malt extract agar, inorganic salts-starch agar, gelatin agar, starch agar, Czapek-sucrose agar, glucose-aspargine agar, and casein agar. In general, the vegetative mycelia of the strains are pale orange to orange yellow, and the aerial mycelia are white to pale yellow. They produce a pale yellowish soluble pigment on Czapek-sucrose agar, glucose-aspargine agar, and calcium malate agar.

Acetate, lactate, malate, pyruvate, succinate, L-arabinose cellobiose, fructose, galactose, glucose, glycerol, inositol, lactose, maltose, mannitol, melezitose, melibiose, $\alpha$-methylD-glucoside, raffinose, L-rhamnose, D-ribose, salicin, starch, sucrose, trehalose, and $\mathrm{D}$-xylose are utilized as carbon sources, but benzoate, citrate, mucate, oxalate, propionate,

TABLE 4. Cellular fatty acid compositions of the isolates

\begin{tabular}{|c|c|c|c|c|c|c|c|c|c|c|c|c|c|c|c|c|c|c|c|c|c|}
\hline \multirow{2}{*}{ Strain } & \multicolumn{21}{|c|}{ Fatty acid composition $(\%)^{a}$} \\
\hline & $14: 0$ & $14: 1$ & i15 & a15 & $15: 0$ & i16 & $16: 0$ & $16: 1$ & $\mathrm{i} 17$ & a17 & $17: 0$ & $17: 1$ & Me17 & i18 & $18: 0$ & $18: 1$ & Me18 & i19 & a19 & $19: 0$ & $19: 1$ \\
\hline RA 327 & 1 & 1 & & & 2 & 11 & 10 & 1 & & 18 & 13 & 10 & 1 & 1 & 4 & 24 & & & & & 5 \\
\hline RA 328 & & 1 & & & 1 & 9 & 9 & 1 & & 17 & 14 & 11 & 1 & 1 & 5 & 26 & & & & & 5 \\
\hline RA 329 & $\operatorname{tr}$ & & 1 & & 1 & 7 & 10 & 1 & & 21 & 16 & 10 & $\operatorname{tr}$ & tr & 6 & 23 & & & $\operatorname{tr}$ & tr & 4 \\
\hline RA 330 & & $\operatorname{tr}$ & & $\operatorname{tr}$ & 1 & 7 & 12 & 2 & & 38 & 6 & 5 & $\operatorname{tr}$ & 1 & 4 & 23 & & & tr & 1 & 1 \\
\hline RA 331 & & $\operatorname{tr}$ & & $\operatorname{tr}$ & $\operatorname{tr}$ & 9 & 10 & 2 & & 38 & 5 & 5 & tr & 1 & 3 & 25 & & & $\operatorname{tr}$ & 1 & 1 \\
\hline RA 332 & & $\operatorname{tr}$ & & 1 & $\operatorname{tr}$ & 8 & 10 & 2 & & 41 & 5 & 6 & $\operatorname{tr}$ & tr & 3 & 22 & & & $\operatorname{tr}$ & tr & 1 \\
\hline RA 336 & $\operatorname{tr}$ & 1 & $\operatorname{tr}$ & $\operatorname{tr}$ & $\operatorname{tr}$ & 7 & 26 & 8 & & 11 & 3 & 4 & tr & & 4 & 32 & & & 1 & $\operatorname{tr}$ & 2 \\
\hline RA 337 & $\operatorname{tr}$ & $\operatorname{tr}$ & $\operatorname{tr}$ & & $\mathrm{tr}$ & 12 & 26 & 5 & & 12 & 3 & 3 & $\mathrm{tr}$ & $\operatorname{tr}$ & 5 & 32 & & & $\mathrm{tr}$ & tr & 1 \\
\hline RA 338 & 1 & $\operatorname{tr}$ & & $\operatorname{tr}$ & 1 & 12 & 25 & 8 & & 13 & 3 & 3 & $\operatorname{tr}$ & $\operatorname{tr}$ & 5 & 28 & & tr & $\operatorname{tr}$ & 1 & $\operatorname{tr}$ \\
\hline RA 343 & 1 & & $\operatorname{tr}$ & & 1 & 2 & 19 & 3 & 11 & & 7 & 6 & $\operatorname{tr}$ & tr & & 49 & $\operatorname{tr}$ & & & $\operatorname{tr}$ & 2 \\
\hline RA 344 & $\operatorname{tr}$ & $\operatorname{tr}$ & & & 1 & 11 & 22 & 7 & & 12 & 4 & 5 & & & 4 & 33 & & & & & 1 \\
\hline IFO $14176^{\mathrm{T}}$ & 1 & $\operatorname{tr}$ & & tr & 1 & 9 & 35 & 7 & & 3 & 7 & 6 & $\operatorname{tr}$ & & 4 & 34 & & & & 1 & 1 \\
\hline IFO 14177 & $\operatorname{tr}$ & & & & $\operatorname{tr}$ & 3 & 15 & 2 & & 19 & 8 & 4 & & $\operatorname{tr}$ & 10 & 37 & & & & $\operatorname{tr}$ & 2 \\
\hline
\end{tabular}

"Abbreviations: $i$, isobranched; a, anteiso branched; Me17, 10-methylheptadecanoic acid; Me18, 10-methyloctadecanoic acid; tr, trace (less than 0.5\%). 
TABLE 5. Levels of DNA-DNA hybridization between isolates

\begin{tabular}{lrrrrrrr}
\hline \multirow{2}{*}{ Strain } & \multicolumn{6}{c}{ DNA-DNA reassociation with: } \\
\cline { 2 - 8 } & RA 327 & RA 328 & RA 330 & RA 332 & RA 337 & RA 343 & N381-16 \\
\hline RA 327 & 100 & 65 & 23 & 20 & 6 & 19 & 9 \\
RA 328 & 75 & 100 & 46 & 45 & 30 & 45 & 25 \\
RA 329 & 73 & 83 & 46 & 42 & 47 & 44 & 26 \\
RA 330 & 10 & 34 & 100 & 91 & 35 & 14 & 38 \\
RA 331 & 29 & 32 & 82 & 78 & 54 & 59 & 35 \\
RA 332 & 38 & 38 & 97 & 100 & 43 & 40 & 30 \\
RA 336 & 23 & 20 & 31 & 32 & 110 & 47 & 22 \\
RA 337 & 8 & ND $^{a}$ & ND & ND & 100 & 11 & ND \\
RA 338 & 23 & 43 & 57 & 50 & 100 & 44 & 63 \\
RA 344 & 49 & 27 & 43 & 52 & 99 & 46 & 49 \\
RA 343 & 20 & ND & ND & ND & 39 & 100 & ND \\
N381-16 & 21 & 18 & 29 & 30 & 15 & 20 & 100 \\
N406-14 & 47 & 35 & 39 & 43 & 36 & 55 & 35 \\
\hline
\end{tabular}

${ }^{a} \mathrm{ND}$, not determined.

dextrin, phenol, ribitol, galactitol, erythritol, sorbitol, and L-sorbose are not utilized.

Acid is produced from L-arabinose, cellobiose, fructose, galactose, glucose, glycerol, inositol, lactose, maltose, mannitol, mannose, melibiose, melezitose, $\alpha$-methyl-D-glucoside, raffinose, L-rhamnose, D-ribose, salicin, starch, sucrose, trehalose, and D-xylose. Acid is not produced from ribitol, galactitol, erythritol, sorbitol, and L-sorbose.

Cell walls contains D-glutamate, D- and L-serine, glycine, D-alanine, and L-lysine (molar ratio, ca. 1:1:1:1:1) and a small amount of L-ornithine. The cell wall type is type VI as defined by Lechevalier and Lechevalier (16). Mannose, xylose, and glucose are present as cell wall sugars. The major cellular fatty acids are Octadecenoic acid (18:1) and hexadecanoic acid (16:0) or anteiso-heptadecanoic acid (a17: $0)$. Mycolic acids are absent. The $G+C$ content of the DNA

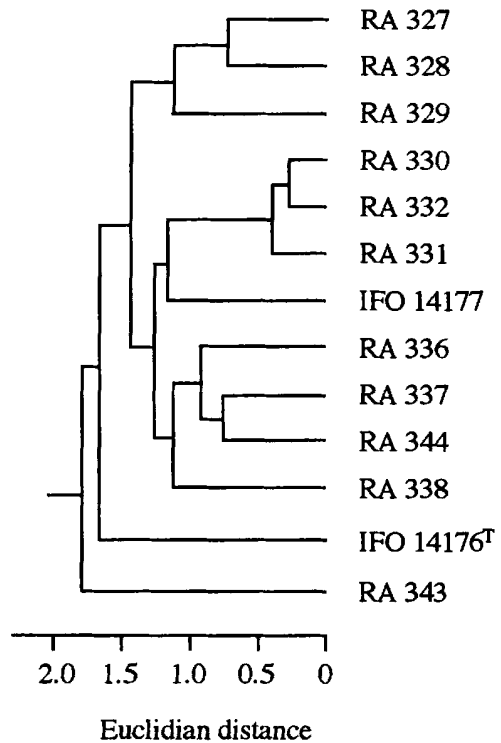

FIG. 3. Dendrogram showing the relationships among the isolates based on fatty acid compositions. Data were analyzed by using the NTSYS-pc program package, and clustering was performed by using the unweighted pair group arithmetic average method.

of the type strain is $71.0 \mathrm{~mol} \%$. The major menaquinones are MK-9 $\left(\mathrm{H}_{8}\right)$ and MK-10 $\left(\mathrm{H}_{8}\right)$; in addition, small amounts of MK-9 $\left(\mathrm{H}_{6}\right)$ and MK-10 $\left(\mathrm{H}_{6}\right)$ are also present. The diagnostic phospholipids are diphosphatidylglycerol, phosphatidylglycerol, phosphatidylinositol, phosphatidylcholine, and phosphatidylethanolamine (type PIII). Habitat: soils.

The type strain is strain N381-16, which has been deposited in the IFO as strain IFO 14176 and in the ATCC as strain ATCC 31637.

TABLE 6. Characteristics that differentiate the genus Catenuloplanes from motile actinomycetes and related actinobacteria ${ }^{a}$

\begin{tabular}{|c|c|c|c|c|c|c|c|c|c|}
\hline Genus & $\begin{array}{r}\text { Aerial } \\
\text { mycelia } \\
\text { formed }\end{array}$ & $\begin{array}{c}\text { Motility of } \\
\text { arthrospores }\end{array}$ & $\begin{array}{l}\text { Sporangia } \\
\text { formed }\end{array}$ & $\begin{array}{l}\text { Motility of } \\
\text { fragmented } \\
\text { cells }\end{array}$ & $\begin{array}{l}\text { Cell wall } \\
\text { type }^{b}\end{array}$ & $\begin{array}{l}\text { Peptidoglycan } \\
{\text { type }(s)^{c}}^{c}\end{array}$ & $\begin{array}{c}\text { Major } \\
\text { menaquinone(s) }\end{array}$ & $\begin{array}{l}\text { Phos- } \\
\text { pholipid } \\
\text { type }\end{array}$ & $\begin{array}{c}\mathrm{G}+\mathrm{C} \\
\text { content } \\
\text { of DNA } \\
(\mathrm{mol} \%)\end{array}$ \\
\hline Catenuloplanes & $t^{d}$ & + & - & - & VI & $\mathrm{ND}^{e}$ & MK-9( $\left.\mathrm{H}_{8}\right), \mathrm{MK}-10\left(\mathrm{H}_{8}\right)$ & PIII & $71-72$ \\
\hline Kineosporia & - & - & + & - & $\mathbf{f}$ & $\mathrm{A} 3 \gamma$ & MK-9( $\left.\mathrm{H}_{4}\right)$ & PIII & $64-69$ \\
\hline Sporichthya & + & + & - & - & I & $\mathrm{A} 3 \gamma$ & MK-9( $\left.\mathrm{H}_{6}, \mathrm{H}_{8}\right)$ & ND & ND \\
\hline Actinoplanes & - & - & + & - & $\mathrm{II}^{\mathrm{g}}$ & $\mathrm{A} 1 \gamma$ & MK-9(H $\left.\mathrm{H}_{4}\right)$,MK-10 $\left(\mathrm{H}_{4}\right)$ & PII & $72-73$ \\
\hline Dactylosporangium & - & - & + & - & II & $\mathrm{Al} \gamma$ & MK-9 $\left(\mathrm{H}_{4}, \mathrm{H}_{6}, \mathrm{H}_{8}\right)$ & PII & $72-73$ \\
\hline Pilimelia & - & - & + & - & II & $\mathrm{Al} \gamma$ & MK-9 $\left(\mathrm{H}_{2}, \mathrm{H}_{4}\right)$ & PII & ND \\
\hline Actinosynnema & + & + & - & - or + & III & $\mathrm{A} 1 \gamma$ & MK-9( $\left.\mathrm{H}_{4}\right), 10\left(\mathrm{H}_{4}\right)$ & PII & $71-73$ \\
\hline Dermatophilus & - & - & - & + & III & $\mathrm{Al} \gamma$ & $\mathrm{MK}-8\left(\mathrm{H}_{4}\right)$ & PI & $57-59$ \\
\hline Geodermatophilus & - & - & - & + & III & $\mathrm{A} 1 \gamma$ & MK-9 $\left(\mathrm{H}_{4}\right)$ & PII & $73-76$ \\
\hline Planobispora & + & - & + & - & III & $\mathrm{A} 1 \gamma$ & MK-9( $\left(\mathrm{H}_{2}, \mathrm{H}_{4}\right)$ & PIV & $70-71$ \\
\hline Planomonospora & + & - & + & - & III & $\mathrm{A} 1 \gamma$ & MK-9( $\left.\mathrm{H}_{2}\right)$ & PIV & 72 \\
\hline Spirillospora & + & - & + & - & III & $\mathrm{Al} \gamma$ & MK-9 $\left(\mathrm{H}_{4}, \mathrm{H}_{6}\right)$ & PI,PII & $69-71$ \\
\hline Streptoalloteichus & + & - & + & - & III & $\mathrm{ND}^{\mathrm{g}}$ & MK-9 $\left(\mathrm{H}_{6}\right), \mathrm{MK}-10\left(\mathrm{H}_{6}\right)$ & PII & ND \\
\hline Actinokineospora & + & + & - & - & IV & Aly & MK-9( $\left(\mathrm{H}_{4}\right)$ & PII & 72 \\
\hline Promicromonospora & + & - & - & - & VI & $\mathrm{A} 4 \alpha$ & MK-9( $\left.\mathrm{H}_{4}\right)$ & PV & $70-75$ \\
\hline Jonesia & - & - & - & + & VI & $\mathrm{A} 4 \alpha$ & MK-9 & ND & $56-58$ \\
\hline Microbacterium & - & - & - & - or + & VI & $\mathrm{B} 1 \alpha, \mathrm{B} 1 \beta$ & MK-11,MK-12 & PI & $60-75$ \\
\hline Cellulomonas & - & - & - & + & VI/VIII & $\mathrm{A} 4 \alpha, \mathrm{A} 4 \beta$ & MK-9 $\left(\mathrm{H}_{4}\right)$ & PV & $72-76$ \\
\hline
\end{tabular}

a Data from references 3,7 through $9,13,14,17,22$, and 29 .

${ }^{b}$ As defined by Lechevalier and Lechevalier (16).

$c$ As defined by Schleifer and Kandler (26).

$d+$, present; - , absent.

e ND, not determined.

$f$ Cell walls contain LL- and meso-DAP (13).

$g$ Actinoplanes caeruleus has type VI cell walls (11). 


\section{ACKNOWLEDGMENTS}

We thank W. D. Celmer for his encouragement and interest in this study and J. E. Bright for expert technical assistance. Appreciation is also expressed to $J$. Jone and $\mathrm{H}$. Maeda for isolating strains $\mathrm{N} 381-16^{\mathrm{T}}$ and N406-14.

\section{REFERENCES}

1. Celmer, W. D., W. P. Cullen, L. H. Huang, J. R. Oscarson, R. Shibakawa, and J. Tone. September 1981. U.S. Patent $4,287,182$.

1a.Container Corporation of America. 1958. Color harmony manual, 4th ed. Container Corporation of America, Chicago.

2. Ezaki, T., Hashimoto, Y., and E. Yabuuchi. 1989. Fluorometric deoxyribonucleic acid-deoxyribonucleic acid hybridization in microdilution wells as an alternative to membrane filter hybridization in which radioisotopes are used to determine genetic relatedness among bacterial strains. Int. J. Syst. Bacteriol. 39:224-229.

3. Goodfellow, M. 1989. The actinomycetes. I. Suprageneric classification of actinomycetes, p. 2333-2339. In S. T. Williams, M. E. Sharpe, and J. G. Holt (ed.), Bergey's manual of systematic bacteriology, vol. 4. The Williams \& Wilkins Co., Baltimore.

4. Gordon, R. E., D. A. Barnett, J. E. Habderhan, and C. H. N. Pang. 1974. Nocardia coeliaca, Nocardia autotrophica, and the nocardin strain. Int. J. Syst. Bacteriol. 24:54-63.

5. Gordon, R. E., and J. M. Mihm. 1957. A comparative study of some strains received as nocardiae. J. Bacteriol. 73:15-27.

6. Harper, J. J., and G. H. G. Davis. 1979. Two-dimensional thin-layer chromatography for amino acid analysis of bacterial cell walls. Int. J. Syst. Bacteriol. 29:56-58.

7. Hasegawa, T. 1988. Actinokineospora, a new genus of Actinomycetales. Actinomycetologica 2:31-45.

8. Hasegawa, T. 1991. Studies on motile arthrospore-bearing rare actinomycetes. Actinomycetologica 5:64-71.

9. Hasegawa, T., M. P. Lechevalier, and H. A. Lechevalier. 1978. New genus of the Actinomycetales: Actinosynnema gen. nov. Int. J. Syst. Bacteriol. 28:304-310.

10. Hayakawa, M., and H. Nonomura. 1987. Humic acid-vitamin agar, a new medium for selective isolation of soil actinomycetes. J. Ferment. Technol. 65:501-509.

11. Horan, A. C., and B. Brodsky. 1986. Actinoplanes caeruleus sp. nov., a blue pigmented species of the genus Actinoplanes. Int. J. Syst. Bacteriol. 36:187-191.

12. Huang, L. H. 1980. Actinomadura marca sp. nov., the producer of antibiotics CP-47,433 and CP-47,434. Int. J. Syst. Bacteriol. 30:565-568.

13. Itoh, T., T. Kudo, F. Parenti, and A. Seino. 1989. Amended description of the genus Kineosporia, based on chemotaxonomic and morphological studies. Int. J. Syst. Bacteriol. 39: 168-173.

14. Jones, D., and M. D. Collins. 1986. Section 15. Irregular, non-sporing Gram-positive rods, p. 1261-1434. In P. H. A. Sneath, N. S. Mair, M. E. Sharpe, and J. G. Holt (ed.), Bergey's manual of systematic bacteriology, vol. 2. The Williams \& Wilkins Co., Baltimore.

15. Kandler, O., and H. König. 1978. Chemical composition of the peptidoglycan-free cell walls of methanogenic bacteria. Arch. Microbiol. 118:141-152.

16. Lechevalier, M. P., and H. A. Lechevalier. 1970. Chemical composition as a criterion in the classification of aerobic actinomycetes. Int. J. Syst. Bacteriol. 20:435-443.

17. Lechevalier, M. P., H. A. Lechevalier, and P. E. Holbert. 1968. Sporichthya, un nouveau genre de Streptomycetaceae. Ann. Inst. Pasteur (Paris) 114:277-286.

18. Lechevalier, M. P., A. E. Stern, and H. Lechevalier. 1981. Phospholipids in the taxonomy of actinomycetes. Zentralbl. Bakteriol. Hyg. Abt. 1 Suppl. 11:111-116.

19. Mesbah, M., U. Premachandran, and W. B. Whitman. 1989. Precise measurement of the $\mathrm{G}+\mathrm{C}$ content of deoxyribonucleic acid by high-performance liquid chromatography. Int. J. Syst. Bacteriol. 39:159-167.

20. Mikami, H., and Y. Ishida. 1983. Post-column fluorometric detection of reducing sugars in high-performance liquid chromatography using arginine. Bunseki Kagaku 32:E207-E210.

21. Minnikin, D. E., L. Alshamaony, and M. Goodfellow. 1975. Differentiation of Mycobacterium, Nocardia and related taxa by thin-layer chromatographic analysis of whole-organism methanolysates. J. Gen. Microbiol. 88:200-206.

22. Minnikin, D. E., M. D. Collins, and M. Goodfellow. 1979. Fatty acid and polar lipid composition in the classification of Cellulomonas, Oerskovia and related taxa. J. Appl. Bacteriol. 47:8795.

23. Pridham, T. G., and D. Gottlieb. 1948. The utilization of carbon compounds by some Actinomycetales as an aid for species determination. J. Bacteriol. 56:107-114.

24. Rocourt, J., U. Wehmeyer, and E. Stackebrandt. 1987. Transfer of Listeria denitrificans to a new genus, Jonesia gen. nov., as Jonesia denitrificans comb. nov. Int. J. Syst. Bacteriol. 37:266270.

25. Saito, H., and K. Miura. 1963. Preparation of transforming deoxyribonucleic acid by phenol treatment. Biochim. Biophys. Acta 72:619-629.

26. Schleifer, K. H., and O. Kandler. 1972. Peptidoglycan types of bacterial cell walls and their taxonomic implications. Bacteriol. Rev. 36:407-477.

27. Shirling, E. B., and D. Gottlieb. 1966. Methods for characterization of Streptomyces species. Int. J. Syst. Bacteriol. 16:313340.

28. Sneath, P. H. A., and R. R. Sokal. 1973. Numerical taxonomy. W.H. Freeman and Co., San Francisco.

29. Stackebrandt, E., and H. Prauser. 1991. Assignment of the genera Cellulomonas, Oerskovia, Promicromonospora and Jonesia to Cellulomonadaceae fam. nov. Syst. Appl. Microbiol. 14:261-265.

30. Suzuki, K., and K. Komagata. 1983. Taxonomic significance of cellular fatty acid composition in some coryneform bacteria. Int. J. Syst. Bacteriol. 33:188-193.

31. Uchida, K., and K. Aida. 1977. Acyl type of bacterial cell wall: its simple identification by colorimetric method. J. Gen. Appl. Microbiol. 23:249-260.

32. Wako Pure Chemical Industries, Ltd. 1989. Technical note for the system of PTC-amino acid analysis. Wako Pure Chemical Industries, Ltd., Osaka, Japan. (In Japanese.) 